\title{
Obsah a cíl výuky psychologie z pohledu studentů učitelských oborů
}

\author{
Alena Nohavová, Lenka Sokolová
}

\begin{abstract}
Abstrakt: Článek je zaméřený na cíle výuky psychologie pro učitelské obory ve vztahu $k$ obsahu výuky. Na tuto problematiku kurikula se diváme skrze výpovédi studentì, kteři absolvovali výuku psychologie na dvou pedagogických fakultách: jedné v České republice a jedné na Slovensku. Z hlediska obecnè formulovaných cílù výuky psychologie - funkčni psychologické gramotnosti - článek nabizi kritický pohled na aplikační rovinu výuky psychologie, kterou studenti kladně hodnoti a vyžaduji, ale se kterou mohou být spojené dva obecné stereotypy vnímáni psychologie: (1) véda, která dává rady, návody, tj. „kuchařky“, a (2) umožňuje „testovat“, poskytuje „testy“.

Uvedené stereotypy vnimáni psychologie totiž stoji na opačném pólu od funkčni psychologické gramotnosti. Identifikaci těchto kritických oblasti cílù výuky psychologie spojených s aplikačni rovinou by méla být vénovaná pozornost napríč formami kurikula. Navrhovaným východiskem je rozvoj kritického a psychologického myšlení ve výuce psychologie.
\end{abstract}

Klíčová slova: funkčni psychologická gramotnost, představy studentů, postoje studentü, výuka psychologie, stereotypy ve výuce, kurikulum.

\section{ÚvoD}

Psychologické disciplíny tvoří integrální součást studia učitelství a významně se spolupodílejí na kvalitě studia učitelství (Stuchlíková, Janík et al., 2015). S ohledem na jejich závažnou roli ve vzdělávání učitelů by se dalo očekávat, že existuje konsenzus na tom, co by mělo být povinnou součástí kurikula psychologie v rámci studia učitelství a jaké by měly být její cíle. Skutečnost tomu však neodpovídá. Studijní plány jednotlivých fakult ukazují, že kurikulum psychologických disciplín se v Čechách a na Slovensku odlišuje např́ic fakultami i univerzitami - co do obsahu, rozsahu i cílů jednotlivých předmětů.

Psychologické disciplíny na fakultách připravujících učitele v Čechách a na Slovensku bývají kromě toho kritizovány za akademické pojetí výuky, které dostatečně neodráží charakter situací a problémů, se kterými se student ve své profesi potká (Pravdová \& Švec, 2014). Tento problém se vedle obsahu týká především cílů výuky. Koncepce cílů výuky v návaznosti na obsah totiž do značné míry rozhoduje o tom, zda ve výuce bude převažovat důraz na ryze akademické znalosti, nebo zda bude brán ohled na jejich vztah k praxi, 
který je pro přípravu učitelů stěžejní. Proto jsme se v tomto článku zaměřily na seznámení $s$ vybranými koncepcemi cílů výuku psychologie na vysokých školách. $\mathrm{Na}$ jejich základě následně analyzujeme představy a postoje studentů učitelských oborů o výuce psychologie a jejích cílech na vysoké škole.

\section{VNITŘNí ČLENĚNÍ CÍLŮ VÝUKY PSYCHOLOGIE JAKO VÝCHODISKO VÝZKUMU}

Současné cíle výuky psychologie, které mají tvořit alternativu ke kritizovanému akademickému pojetí, jsou v obecné rovině shrnuté pod zastřešujícím termínem funkčni psychologická gramotnost (McGovern et al., 2010 ad.). Původní pojetí psychologické gramotnosti - bez jejího zaměření na funkčnost - bylo představeno $\mathrm{v}$ podobě základních znalostí: 100 základních pojmů z psychologie (Boneau, 1990). Následný vývoj pojmu psychologická gramotnost se od tohoto pojetí odklonil směrem $\mathrm{k}$ funkčni gramotnosti. $\mathrm{V}$ pojetí postaveném na konstruktu funkční gramotnosti nejde pouze o znalost pojmů a pravidel, ale také o způsobilost jejich užití v celém rozsahu očekávaných schopností a dovedností (Chrz, Nohavová \& Slavík, 2015).

„Psychologicky gramotný člověk reflektuje chování anebo mentální procesy, rozumí jim jak u druhých lidí, tak u sebe a je schopen aplikovat znalost psychologických principů na reálné personální, sociální a ří- dicí aktivity v práci, mezilidských vztazích i v širším společenském kontextu" (McGovern et al., 2010, s. 11). Tyto obecné cíle psychologického vzdělávání jsou uznané a dále rozpracovávané do konkrétní podoby po celém světě (např. Cranney $\&$ Dunn, 2011; Dunn et al., 2013; Mair, Taylor \& Hulme, 2013; Taylor \& Hulme, 2015; Chrz, Nohavová, \& Slavík, 2015; Sokolová, 2015 aj.).

Koncept výuky psychologie založené na funkční gramotnosti se původně týkal univerzitní prŕípravy studentů psychologie. V současné době se však otevírá prostor pro diskusi, zda toto pojetí nerozšriritit nad rámec oborového studia psychologie, tj. na všechny stupně a typy vzdělávání (Sokolová, 2018). Podporou pro tuto úvahu je koncept psychologicky gramotného občana (Halpern, 2010, s. 7): „... psychologicky gramotný občan je schopen uplatňovat základní znalosti psychologie v široké škále situací." Tím je koncept funkční psychologické gramotnosti rozšíren i na vysokoškolské vzdělávání nepsychologických oborů, potažmo střední školy. ${ }^{1}$

Pojetí funkční psychologické gramotnosti a psychologicky gramotného občana do jisté míry splývá $s$ kompetenčním př́istupem ke vzdělávacím cílům. Všechny tyto prrípady se totiž společně týkají „umění jednat stejně jako reflektujícího věděni o jednáni"(Slavík et al., 2017, s. 193). Problém takto nastavených cílů je však v tom, že jsou př́lišs obecné.

Vysoká míra jejich obecnosti může vést ke zkreslující představě, že „všechno“,

\footnotetext{
${ }^{1}$ Např́íklad Evropská federace asociací učitelů psychologie (EFPTA) se zaměřuje na podporu rozvoje funkční psychologické gramotnosti prostřednictvím výuky psychologie již u žáků a studentů ve věku 13-19 let.
} 
co student učitelství ve výuce psychologie "děláa, „nějak“ rozvíjí funkční psychologickou gramotnost a tím student nabývá psychologickou kompetenci pro pedagogické jednání. Proto je nezbytné, aby uvedený obecný prrístup byl nahrazen analytičtěším pohledem. Ten by měl zabezpečit přesnější náhled na identifikaci obsahu i cílů a kritérií pro vyhodnocení kvality výuky. Východiskem pro jejich stanovení jsou konkrétní oblasti (dimenze) funkční psychologické gramotnosti. McGovern a kol. (2010, s. 11), jedni z autorů konceptu funkční psychologické gramotnosti, navrhli následujících devět oblastí:

1. mít dobře definovanou terminologii a základní znalosti kritického předmětu psychologie;

2. oceňovat intelektuální výzvy potřebné pro využití vědeckého myšlení a korektní analýzu informací $\mathrm{k}$ vyhodnocení alternativních akčních postupů;

3. přijmout kreativní a př́větivě skeptický př́stup $\mathrm{k}$ řešení problémů;

4. uplatňovat psychologické principy na osobní, sociální a organizační záležitosti v práci, vztazích a širší komunitě;

5. etický př́istup;

6. schopnost využívat a vyhodnocovat informace a technologie;

7. komunikovat efektivně v různých situacích a s mnoha různými lidmi;

8. uznávání, porozumění a podporování respektu k rozmanitosti;

9. být všímavý a reflektovat chování a duševní procesy své a druhých.

Sokolová (2015) tyto cíle dále rozřadila do následujících pěti oblastí na vyšší úrovni zobecnění, které mají prrispět $\mathrm{k}$ využití to- hoto systému cílů pro psychologické vzdělávání učitelů:

- sebepoznání (oblasti 4, 9),

- vědecké myšlení (oblasti $1,2,4,6$ ),

- kritické myšlení (oblasti 3, 4, 6, 7),

- psychologické myšlení (oblasti 4, 6, 7, 8),

- další oblasti funkční psychologické gramotnosti (oblast 5).

Výše uvedené oblasti funkční psychologické gramotnosti jsme použily jako základní kategorie pro analýzu zkušeností studentů $\mathrm{z}$ výuky psychologie $\mathrm{v}$ učitelských oborech na dvou záměrně vybraných pedagogických fakultách, jedné z České republiky a jedné ze Slovenska.

\section{Nahlížení na výzkum výuky psychologie $\mathrm{z}$ hlediska forem kurikula}

Náš výzkum je zaměřený na obsah výuky psychologie ve vztahu $\mathrm{k}$ jejím cílům a patř́ tedy do problematiky kurikula. Kurikulum je zde v souladu s $P e-$ dagogickou encyklopedií (Průcha, 2009, s. 117) chápáno nejenom jako vyučovací plán a vymezení vzdělávacího obsahu, ale jako „obsah vzdělávání, který zahrnuje veškeré zkušenosti, které studenti získávají ve škole a v činnostech ke škole se vztahujících, zejména jejich plánování, zprostředkování a hodnocení." Vzhledem k tomu, že pohlížíme na kurikulum hlavně prostřednictvím jeho adresátů - studentů, potřebujeme se opírat o takovou koncepci kurikula, která umožní brát $\mathrm{v}$ úvahu vztahy mezi adresáty vzdělávání, vzdělávacím obsahem a cíli. K tomu jsme využily Průchovu 
koncepci, která řeší napětí mezi plánovaným a realizovaným obsahem vzdělávání prostřednictvím tzv. forem existence obsahu vzděláváni (Průcha, 2005). Průcha rozlišuje pět těchto úrovní:

1. koncepční - koncepce, vize, plány obsahu vzdělávání na té nejobecnější úrovni;

2. projektovou - konkrétní plánované projekty (vzdělávací programy, učební plány a osnovy škol a předmětů);

3. realizační - konkrétní realizace obsahu vzdělávání;

4. rezultátovou - obsah vzdělávání osvojený subjekty edukace;

5. efektovou - efekty obsahu vzdělávání, které se promítají do profesní kariéry.

Uvedené úrovně forem kurikula na sebe vzájemně navazují, takže rezultátová úroveň reprezentuje ty úrovně, které jí předcházejí. Na tomto teoretickém přístupu je postavený prezentovaný výzkum. Zaměřujeme se na zkoumání zkušeností studentů $s$ výukou psychologie, tj. na rezultátovou úroveň formy kurikula. To je východisko, na jehož podkladě získáváme informace o realizační formě a tu porovnáváme $s$ projektovou a koncepční úrovní formy kurikula. Ve výzkumu jsme sice nesledovaly bezprostředně výuku, tj. realizační formu, přesto však považujeme výpovědi studentů za dostatečně závažný zdroj informací o předcházejících úrovních kurikula a za indikátor reálných kvalit výuky. Předpokládáme, že výpovědi studentů o jejich zkušenostech z výuky psychologie nám poskytují př́nosné údaje o skutečně realizovaném obsahu této výuky a o tom, jakými cíli byla výuka podmíněna.

\section{VÝZKUMNÉ PROBLÉMY SPOJENÉ $S$ VÝUKOU PSYCHOLOGIE}

Na uvedeném předpokladu, tj. propojení úrovní forem obsahu vzdělávání, jsme se zaméřily na tři problémové okruhy spojené s výukou psychologie. První se týkal výsledků studia vzhledem $\mathrm{k}$ jeho př́nosu uvedeného studenty na základě jejich zkušeností $\mathrm{z}$ výuky. $\mathrm{V}$ druhém jsme věnovaly pozornost znalostem studentů o ústředním cíli výuky psychologie: psychologické gramotnosti. Ve třetím okruhu jsme chtěly zjistit, jak studenti vnímají (zejména $\mathrm{v}$ afektivní rovině) klíčové pojmy, které zastřešují studium psychologie $\mathrm{v}$ učitelských programech. $\mathrm{K}$ těmto třem problémovým okruhům zde nejprve uvedeme základní informace, potom je vyložíme podrobněji.

$\mathrm{K}$ prvnímu okruhu jsme získávaly informace pomocí otevřených otázek. Ptaly jsme se studentů (anonymně) na př́nosy konkrétní výuky psychologie (realizované na sledovaných fakultách). Kromě toho jsme se ptaly, co jim v předmětu chybělo. Přitom jsme rozlišovaly (a) př́nos osobní - pro samotné studenty - a (b) prínos profesní. Rozlišení osobní a profesní oblasti vnímáme jako důležité $\mathrm{z}$ toho důvodu, že budoucí učitelé musí rozvíjet obě dvě oblasti zároveň. $V$ reakcích studentů na otázky $\mathrm{v}$ těchto dvou oblastech jsme získávaly zprostředkované informace o tom, nakolik je výuka z pohledu studentů vstřícná $\mathrm{k}$ praxi.

V druhém okruhu jsme se studentů ptaly, opět pomocí otevřené otázky, co si představují pod pojmem psychologická gramotnost, a to před semestrem a po semestru. Předpokládáme, že se do výpovědí studentů 
po semestru jednak implicitně promítne nastavení výuky samotné (projektová úroveň formy obsahu vzdělávání). Dále ale také předpokládáme, že jejich výpovědi nám ukáží, které sledované obecněǰši kategorie cílů studenti uvedou a které naopak v jejich výpovědích budou chybět, respektive nejsou pro studeny tak zřetelné, aby je do výpovědi zahrnuli. V tomto př́padě skrze rezultátovou úroveň sledujeme i koncepční úroveň formy obsahu vzdělávání. Výsledky potom vytvárejí předpoklad pro úvahy o kritických oblastech cílu výnky psychologie na úrovni projektové a koncepční.

Ve třetím okruhu jsme se zaměrily prostřednictvím škál sémantického diferenciálu na afektivní dimenzi (vztahovou a významovou) ke třem pojmům: psychologie, psychologie v uciitelské profesi, psychologická gramotnost. Zajímalo nás, jak se studenti vztahují k uvedeným pojmům na afektivní úrovni a dále nás zajímal posun $\mathrm{v}$ jejich vnímání na základě realizované výuky. Očekávaly jsme, že škály sémantického diferenciálu nám poskytnou ,jemnější informace o tom, jak studenti přistupují $\mathrm{k}$ obsahu a cílům výuky psychologie, jaké konotativní významy jim připisují.

Výzkumné otázky:

VO1 Které předmětové cíle výuky psychologie jsou obsažené ve výpovědích studentů $\mathrm{k}$ realizovaným předmětům na pedagogické fakultě v ČR a SR?

VO2 Které dimenze funkční psychologické gramotnosti jsou obsažené ve výpovědích studentů $\mathrm{k}$ realizovaným předmětům na pedagogické fakultě v ČR a SR?
VO3 Jak se vyvíjí afektivní dimenze konotací $\mathrm{k}$ pojmu psychologie, psychologie $\mathrm{v}$ učitelské profesi, psychologická gramotnost u studentů na základě realizované výuky psychologie?

VO4 Jak se vyvíjí kognitivní dimenze pojmu psychologická gramotnost u studentů na základě realizované výuky psychologie?

\section{Výzkumný soubor, metody sběru dat a jejich analýza}

Sběr dat probíhal na Pedagogické fakultě JU v Českých Budějovicích (dále PedF JU) a na Pedagogické fakultě UK v Bratislavě (dále PedF UKB) v povinných předmětech v zimním semestru 2017/2018.

Pedagogická fakulta JU v Českých Budějovicích: Studenti absolvovali předmět Úvod do psychologie v 1. ročníku bakalárského oboru $(\mathrm{N}=153)$. Předmět byl vyučovaný $\mathrm{v}$ rozsahu jedna přednáška a jeden seminár týdně. Byl to první předmět $\mathrm{z}$ psychologie, který studenti $\mathrm{v}$ rámci studia absolvovali. Základní nastavení předmětu bylo vedeno představou, že ne všichni studenti na střední škole měli výuku psychologie, a tudíz je potřeba poskytnout jim základní informace o psychologii. $\mathrm{V}$ předmětu byla probíraná témata především z obecné psychologie (determinace, vědomí, vnímání, pozornost, pamět, inteligence, emoce, učení, myšlení, motivace). Přednášku vedla jedna vyučující, semináŕe celkem čtyři vyučující (obsah seminárù a způsob jejich uchopení byl u vyučujících rozdílný). Předmět byl primárně nastavený 
na znalostní rovinu a porozumění základním pojmům a tématům psychologie, jak je uvedeno $\mathrm{v}$ akademickém informačním systému. Aplikační rovina byla př́tomná v podobě analýzy osobní zkušenosti.

\section{Pedagogická fakulta UK v Bratislavě:} Studenti absolvovali předmět Psychologie pro učitele 2 ve 2 . ročníku bakalářského studia oboru $(\mathrm{N}=100)$, který se skládal $\mathrm{z}$ přednášky a semináře $\mathrm{v}$ rozsahu dvě přednášky a dva semináre týdně. Jde o druhý povinný předmět, který studenti $\mathrm{v}$ rámci studia absolvovali. $\mathrm{V}$ předmětu byla probíraná témata psychologie osobnosti s důrazem na interindividuální rozdíly (determinace osobnosti, typologie osobnosti, temperament, motivace, inteligence, zvládání zátěže, duševní zdraví, osobnost učitele) a vybraná témata pedagogické psychologie (učení, kreativita, sociální dynamika školní třídy, kognitivní styly, strategie učení, poruchy učení a chování). Přednášku i semináře vedla stejná vyučující. Semináre byly zaměřené zejména na analýzu různých typů prípadových studií a kazuistik ze školní praxe ve vztahu $k$ tématům jednotlivých přednášek. Předmět byl nastavený na znalostní, dovedností i aplikační rovinu, jak je uvedeno $\mathrm{v}$ akademickém informačním systému.

Ze základní charakteristiky je patrné, že se jedná o rozdílné předměty co do nastavení témat, cílů výuky, časové dotace vedení výuky vyučujícím. Tato rozdílnost výzkumných souborů je $\mathrm{z}$ našeho pohledu př́nosem, protože všechny uvedené vlivy mohou zasahovat do výuky psychologie a my se na ně díváme ve vzájemných sémantických a logických vazbách, a to na- příć úrovněmi kurikula. Neaspirujeme na zobecnitelnost poznatků na populaci, naším cílem je uvědomit si tyto sémantické a logické vztahy mezi úrovněmi kurikula a lépe jim porozumět - způsob představení a interpretace dat jsou vedeny tímto záměrem.

Výpovědi studentů $\mathrm{k}$ př́nosům a oblastem, které jim v předmětech chyběly, jsme analyzovaly kvalitativně pomocí tzv. otevřeného kódování. Použily jsme tedy induktivní analýzu dat, ale s předem strukturovanou oporou, kterou nám poskytly výše uvedené dimenze funkční psychologické gramotnosti. Náš př́stup tím stojí na pomezí obsahové analýzy (opřené o předběžnou kategorizaci) a typického kvalitativního výzkumu (v němž se kategorie vynořují teprve během analýzy údajů). Tento př́istup jsme volily proto, abychom zjistily, jakým způsobem mohou být dimenze funkční gramotnosti obsaženy v našich údajích, ale zároveň si ponechaly otevřené možnosti pro zjištění těch témat, která přesahují jejich rámec.

Otevřené kódování jsme realizovaly na základě výše uvedených dimenzí funkční psychologické gramotnosti (McGovern et al., 2010). Předem jsme tudíž měly stanovený seznam kategorií: znalosti, védecké myšleni, rèseneni problémi, aplikace, etika, zacházeni s informacemi a technologiemi, komunikace, respekt $k$ rozmanitosti, sebepoznáni, poznáni druhých. Pokud výpovědi studentů uvedené kategorie neobsahovaly, vytvořily jsme nové kódy. Nově vytvořenými kódy se staly: testováni ( $v$ podobè testu osobnosti), užité metody a didaktické materiály, praktické ukázky a cvičeni, dalsí témata, 
orientace na žáka (včetnè orientace na problémového žáka), řšeni problému ve škole, organizační požadavky. Analyzované kategorie a kódy následně představujeme pomocí metody tzv. výkladu karet (Švaříček, Šed'ová et al., 2007). Oblast př́nosu jsme zjištovaly i na procentuální škále 0-100\% (pro obě zmíněné oblasti - pro studenty samotné a pro jejich budoucí profesi) a výsledky uvádíme v podobě deskriptivní statistiky.

Dále jsme se studentů ptaly, opět pomocí otevřené otázky, co si představují pod pojmem psychologická gramotnost, a to před semestrem a po semestru. Odpovědi jsme opět kódovaly pomocí otevřeného kódování. Zde jsme se dívaly na úplně základní kategorie funkční psychologické gramotnosti: (a) znalost a (b) aplikace. Při jejich analýze $\mathrm{v}$ odpovědích studentů vznikly jejich póly. U kategorie znalosti vytvořenými póly jsou: základy (přehled) zvládání, u kategorie aplikace: obecnost konkrétnost. $\mathrm{Z}$ analýzy se následně ukázala ještě třetí kategorie: znalost spolu s aplikací a taktéž vznikla nová kategorie: nevim. Výsledky uvádíme v kvantitativní i kvalitativní podobě.

$\mathrm{V}$ neposlední řadě jsme se zaměrily i na zjištování afektivního postoje studentů ke třem základním pojmům, které zastřešují obsah i cíle studia psychologie: $p s y$ chologie, psychologie v učitelské profesi, psychologická gramotnost. Šlo nám především o zjištění posunu tohoto postoje během studia. Proto jsme porovnávaly výsledky před semestrem a po semestru. K získání informací jsme využily škály sémantického diferenciálu ${ }^{2}$ (srov. Doulík \& Škoda, 2003). Metoda sémantického diferenciálu byla pro nás prrínosná tím, že dovoluje orientaci v kvalitativních charakteristikách postojů $\mathrm{k}$ určitému tématu, resp. pojmu, ale zároveň je vhodná pro statistické zpracování díky škálám sémantického diferenciálu. Tuto metodu jsme uplatnily pro vztahový aspekt (tendence $\mathrm{k}$ přijetí/odmítání) a pro aspekt významový (významové konotace). Statistické porovnání výsledků (a) mezi soubory na zaćátku semestru a (b) u souborů zvlášt (porovnání před a po semestru) nám slouží $\mathrm{k}$ úvahám o vlivech, které se do výsledků mohly promítnout.

\section{VÝSLEDKY HODNOCENÍ}

\section{ABSOLVOVANÉHO PŘEDMĚTU \\ Z PSYCHOLOGIE STUDENTY}

Hodnocení výuky psychologie pomocí procentuálního vyjádření prrínosu uvedlo 142 studentů z Pedagogické fakulty JU v Českých Budějovicích a 100 studentů z Pedagogické fakulty UK v Bratislavě.

Studenti z PedF JU předmět hodnotí jako: (a) prínosný pro mě ze 74,47\% (modus 70, medián 75), (b) př́nosný pro profesi ze 75,37\% (modus 70, medián 80 ).

Studenti z PedF UKB předmět hodnotí jako: (a) př́nosný pro mě ze $82,98 \%$ (modus 90 , medián 87 ), (b) př́nosný pro profesi z 92,81\% (modus 100, medián 95).

\footnotetext{
${ }^{2}$ Metoda sémantického diferenciálu je využívaným výzkumným nástrojem na PedF JU v Českých Budějovicích. Kromě výše uvedeného předmětu Úvod do psychologie byl tímto způsobem např. sledován postoj studentů k pojmům vztahujícím se k reflektivnímu a transmisivnímu procesu učení (více Žlábková \& Krninský, 2013).
} 
Celkově výuka psychologie na PedF UK v Bratislavě je hodnocena jako přínosnější $\mathrm{v}$ obou dvou sledovaných aspektech. Zatímco u souboru z PedF JU studenti hodnotili předmět jako shodně př́nosný pro sebe i pro profesi, u souboru z PedF UK v Bratislavě byl předmět $\mathrm{z}$ hlediska jejich budoucí profese studenty hodnocen ještě př́nosněji než pro ně samotné. Jestliže rezultátová forma odráží realizační formu obsahu vzdělávání, můžeme říci, že studenti přijali konkrétní způsob realizace obsahu vzdělávání.

Připomeňme, že na úrovni projektové formy obsahu vzdělávání byl na PedF JU předmět více orientovaný na znalostní stránku (zčásti realizovaný přes osobní zkušenosti studentů), na PedF UKB byl předmět více orientovaný na dovednostní a aplikační rovinu než na rovinu znalostní, jak je uvedeno $\mathrm{v}$ cílech předmětů v oficiálním informačním systému. Dále připomeňme, že zatímco na PedF JU byl předmět zaměřený na témata z obecné psychologie, na PedF UKB to byla témata $\mathrm{z}$ psychologie osobnosti a pedagogické psychologie. Již samotná témata $\mathrm{v}$ předmětech byla rozdílná právě z hlediska jejich uplatnění v osobním a profesním životě, což se mohlo promítnout do závěrečného hodnocení výuky studentů. Kromě toho je potřeba upozornit, že předmět na PedF JU byl vedený více vyučujícími, na PedF UKB to byla jedna vyučující. Rovněž časová dotace byla rozdílná - na PedF UKB to byl dvojnásobek. Posledním důležitým rozdílem je, že na PedF JU studenti byli v prvním ročníku a byl to jejich první předmět z psychologie na vysoké škole, zatímco na PedF UKB byli studenti již ve druhém ročníku. $Z$ praxe víme, že první ročníky na vysoké škole se od druhých výrazně liší. Všechny tyto vlivy, o kterých víme, ale cíleně jsme je nesledovaly, se mohly promítnout do odpovědí studentů. Proto pro lepší porozumění konkrétním kategoriím př́nosů a nedostatků dále uvádíme kvalitativní analýzu odpovědí studentů.

\section{Hodnocení a představy studentů o výuce psychologie na základě jejich zkušeností}

Studenti př́nos výuky uváděli v oblasti znalostí (pojmì, poznatkĩ). U souboru z PedF JU se jednalo o př́nos popisovaný v poměrně obecné rovině jako osvojení si základů z psychologie, opakování znalostí ze střední školy či jejich rozšíření. U souboru z PedF UKB byly znalosti uváděny ve vztahu ke konkrétním probíraným tématům (stres, typologie osobnosti, kreativita). Další shodnou kategorií bylo sebepoznáni (uvědomování si některých svých vlastností, způsobů chování atd.) a poznáni druhých. U českého souboru byla dále kladně hodnocena i možnost testováni sama sebe. U slovenského souboru byly kladně hodnoceny některé použité metody a didaktické materiály (videa, př́klady, diskuse).

Rovina prínosu pro profesi byla zmiňovaná u obou souborů ve vztahu ke konkrétním probiraným tématům. $\mathrm{V}$ menší míre byl zmiňovaný př́nos $\mathrm{v}$ oblasti sebe- 
poznáni a sebeuvédomováni v učitelské profesi (např. odpovědi z PedF UKB: „uvědomuji si potřeby dětí s různými poruchami učení", „nové aktivity, které bych mohla použít ve své trí́dě“ apod.). U souboru z PedF UKB byly dále zaznamenané odpovědi týkající se konkrétních př́kladů a situací ze školní praxe. U souboru z PedF JU byla naopak zmiňována znalostní rovina.

$\mathrm{Na}$ otázku, co studentům ve výuce psychologie chybèlo (pro né samotné), byly častými odpověd'mi: nevím, nechybělo nic, resp. nedokázali na otázku odpovědět. V souboru z PedF JU bylo požadavkem zařadit více praktických ukázek a cvičení, seberozvoj a sebepoznání, testy osobnosti. Dále byl uveden požadavek na větší hloubku probíraných témat, zařazení dalších témat (komunikace, emoce, stres, duševní hygiena). Objevoval se i požadavek na větší zaměření na žáka (ve smyslu komunikace s problémovým žákem; jak reagovat na to, co žák dělá; jak se chovat; sociální úlohy). U souboru z PedF UKB kromě organizačních požadavků na předmět (rozsah, navazující předměty v rozvrhu, ztížená koncentrace apod.) se někteří studenti vyjádřili, že by uvítali více osobnostních testů, praktických cvičení a skupinových aktivit. I když tyto výukové metody byly $\mathrm{v}$ předmětu zařazeny, studenti by je přijali ve větší míře.

$\mathrm{Na}$ otázku, co studentům v předmětu chybèlo pro jejich profesi, stejně jako v předešlé otázce obvykle odpovídali: nevím, nechybělo nic, resp. nedokázali na otázku odpovědět. Nejžádanější „poptávkou“ se stala na PedF JU oblast dítě a jeho psychika a dítě ve školním kontextu, tj. psycho- logie dítěte a pedagogická psychologie, a to $\mathrm{v}$ podobě praktických ukázek, příkladů, praxe. Dále práce s problémovým žákem a řešení problémů ve škole obecně. Pokud studentům na PedF UKB něco scházelo, bylo to intenzivnější propojení $s$ praxí - více ukázek a návodů, jak pracovat $s$ dětmi, více př́ikladů řešení různých situací, více času na procvičení prezentovaných poznatků apod.

Z hlediska dimenzí funkční psychologické gramotnosti (koncepční úrovně formy kurikula) byly podle výpovědí studentů rozvíjené především dimenze vědeckého myšlení (v rovině znalostí a jejich porozumění), dále sebepoznání a poznání druhých.

$\mathrm{Na}$ úrovni realizační formy se znovu ukazuje, stejně jako z procentuálního vyjádření př́nosu předmětů, že studenti na obou dvou sledovaných fakultách přijali strukturu a pojetí předmětu, která byla rozdílná. Rozdílnost vycházela již z projektové úrovně formy obsahu vzdělávání. Jak bylo uvedeno, na PedF JU byl předmět orientovaný primárně na úroveň znalostí a jejich porozumění. Na PedF UKB byl předmětu zaměřen na znalostní i dovednostní a aplikovanou rovinu. Právě to studenti z PedF UKB nejvíce oceňovali (i když by toho podle některých vyjádření mohlo být více). Studenti z PedF JU ve větší míre požadovali rovinu praktických, aplikovaných, konkrétních př́kladů, a to jak pro svůj osobnostní rozvoj, tak pro praxi (se zaměřením na žáky). Přestože podle vyučujících byly studentům PedF JU dávány př́klady a ukázky, jak psychologické pojmy a teorie vidět $\mathrm{v}$ běžném ži- 
votě i v jejich budoucí profesi, z pohledu studentů jich bylo málo. Studenti obecně požadují vice konkrétnich, praktických a aplikovatelných prìkladù ve všech rovinách - já, žák, já jako učitel. Toto téma bude rozvedeno $\mathrm{v}$ diskusní části ve vztahu $\mathrm{k}$ cílům výuky psychologie a jejich nástrahám.

Velmi nízký počet odpovědí na otáz$\mathrm{ku}$, co studentům v předmětu chybí pro ně a pro profesi, odkazuje na spokojenost $s$ předměty, zároveň ale otevírá prostor pro úvahy, jestli studenti maji uchopené cile výuky psychologie (co od ni očekávaji pro sebe a pro svoji profesi) a v jaké konkrétní podobè si predstavuji jejich naplnèni. Tato úvaha bude také rozvedena v diskusní části.

\section{AfEKTIVNí DIMENZE K POJMŮM: PSYCHOLOGIE, PSYCHOLOGIE V UČITELSKÉ PROFESI, PSYCHOLOGICKÁ GRAMOTNOST}

Afektivní dimenze byla sledovaná u studentů (PedF JU N = 153, PedF UKB $\mathrm{N}=100)$ před semestrem a po něm ke třem sledovaným pojmům: psychologie (graf 1), psychologie v učitelské profesi (graf 2), psychologická gramotnost (graf 3). Sledovaná afektivní dimenze ke třem pojmům (psychologie, psychologie $\mathrm{v}$ učitelské profesi, psychologická gramotnost) ukazuje, že psychologie je u studentů z hlediska

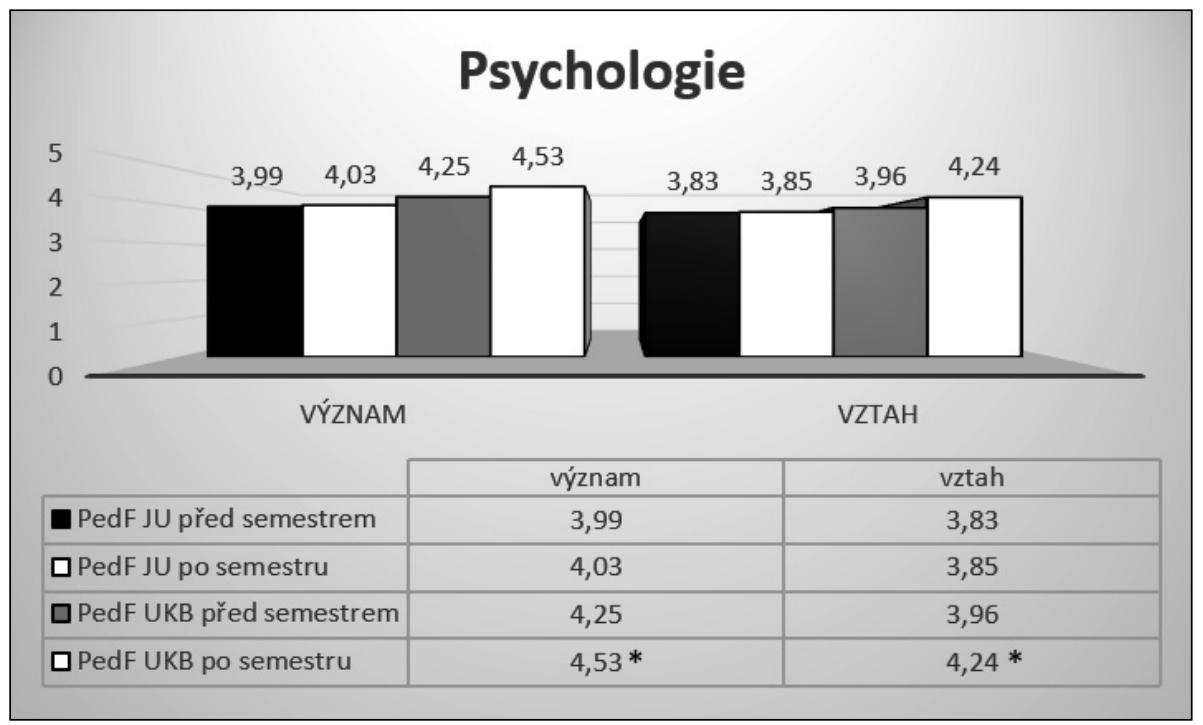

Graf 1. Afektivní dimenze (významová a vztahová rovina) před semestrem a po semestru k pojmu psychologie u souboru PedF JU $(\mathrm{N}=153)$ a PedF UKB $(\mathrm{N}=100)$. Označené rozdíly $\left(^{*}\right)$ před semestrem a po semestru u souboru PedF UKB na úrovni významu i vztahu jsou statisticky významné (párový t-test, hladina významnosti 0,05 ) 


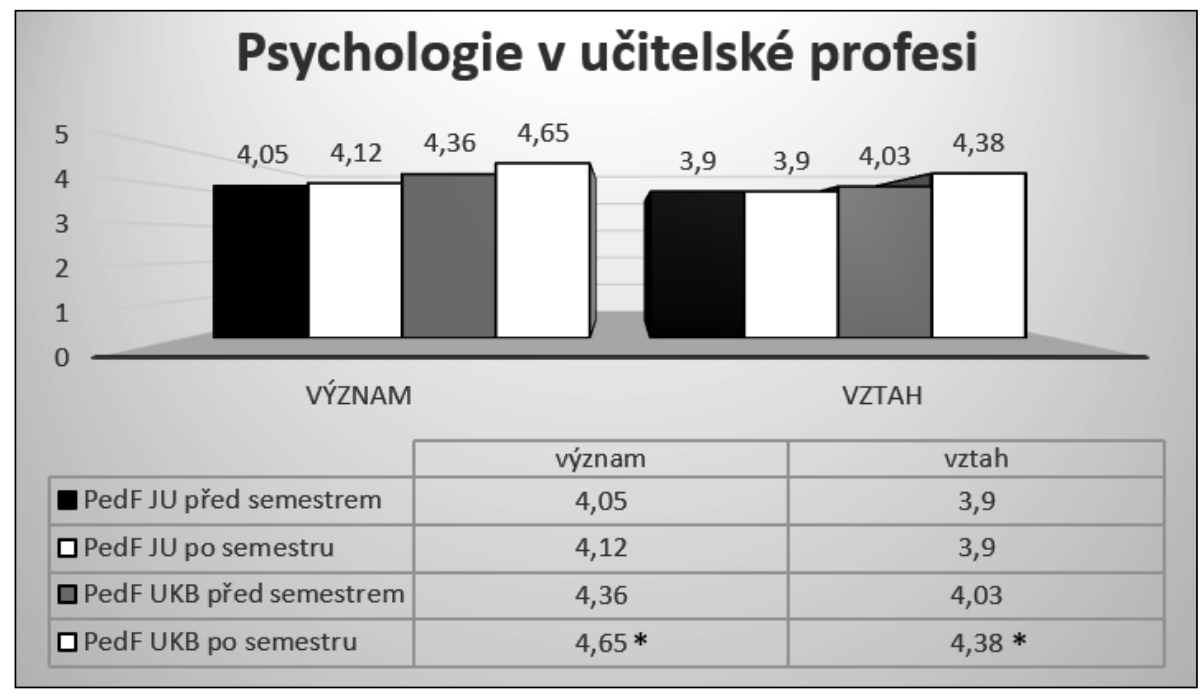

Graf 2. Afektivní dimenze (významová a vztahová rovina) před semestrem a po semestru k pojmu psychologie v učitelské profesi u souboru PedF JU (N = 153) a PedF UKB (N=100). Označené rozdíly $\left(^{*}\right)$ před semestrem a po semestru u souboru PedF UKB na úrovni významu i vztahu jsou statisticky významné (párový t-test, hladina významnosti 0,05 )

významu: užitečná, známá, významná, potřebná a moderní. Na úrovni vztahu je pro studenty výuka: dobrá, důvěrují jí, líbí se jim, je oblíbená a bezpečná. Hodnocení výuky psychologie na vysoké škole pomocí afektivní dimenze potvrzuje současný trend sledovaný již na středních školách. Výuka psychologie na střední škole patří u studentů v evropských zemích mezi oblíbené předměty (Augustin, 2012) a v našich souborech v České republice i na Slovensku kladný postoj $\mathrm{k}$ výuce psychologie pokračuje i na vysoké škole (v bakalářském studiu).

Ze statistického hlediska (t-test pro nezávislé vzorky) se ukazuje, že již před semestrem je statisticky významný rozdíl (na hladině významnosti 0,05$)$ mezi českým a slovenským souborem na úrovni významu u pojmů psychologie a psychologie $\mathrm{v}$ učitelské profesi. Větší význam, který těmto pojmům přikládají studenti slovenského souboru (PedF UKB), může být daný např́klad realizovanou výukou v druhém ročníku vysoké školy a způsobem vedení výuky. Na úrovni vztahu mezi soubory není statisticky významný rozdíl u žádného ze tř́ pojmů.

Zatímco u slovenského souboru po semestru je statisticky významný rozdíl (párový t-test, hladina významnosti 0,05 ) ve vnímání všech třech pojmů (psychologie, psychologie v učitelské profesi, psychologická gramotnost) v rovině vztahu 


\section{Psychologická gramotnost}

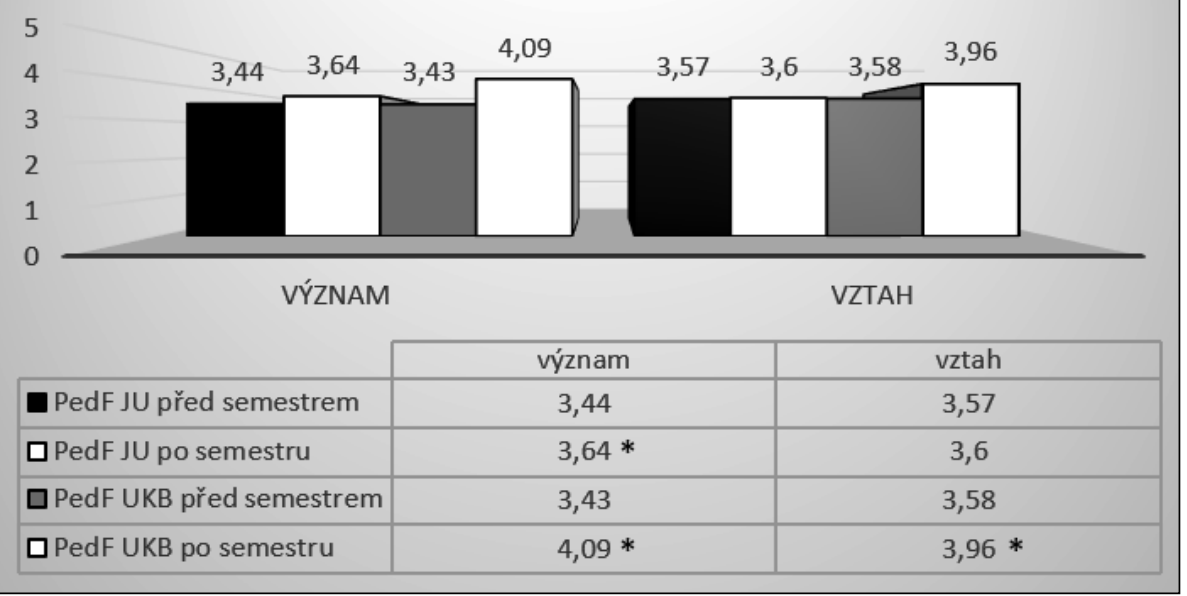

Graf 3. Afektivní dimenze (významová a vztahová rovina) před semestrem a po semestru k pojmu psychologická gramotnost u souboru PedF JU $(\mathrm{N}=153)$ a PedF UKB $(\mathrm{N}=100)$. Označené rozdíly $\left(^{*}\right)$ před semestrem a po semestru u souboru z PedF UKB jsou na úrovni významu i vztahu statisticky významné (párový t-test, hladina významnosti 0,05 ). U souboru z PedF JU je statisticky významný rozdíl před a po semestru na úrovni významu

i významu, u českého souboru je to pouze u pojmu psychologická gramotnost v rovině významu. Co tyto výsledky ukazují, to nám může blíže napovědět kvalitativní analýza k pojmu psychologická gramotnost před semestrem a po semestru u těchto dvou souborů.

\section{ANALÝZA POJMU FUNKČNÍ PSYCHOLOGICKÁ GRAMOTNOST PŘED A PO SEMESTRU}

Jak bylo uvedeno v kapitole 3, dále jsme sledovaly kognitivni dimenzi u pojmu psychologická gramotnost. Pojem samotný nebyl $\mathrm{v}$ předmětu vyučován, protože nemělo dojít $\mathrm{k}$ "pouhému“ naučení pojmu a jeho významu (viz Morris et al., 2013). U ostatních dvou pojmů (psychologie, psychologie $\mathrm{v}$ učitelské profesi) jsme kognitivní dimenzi nesledovaly, protože jsme předpokládaly, že budou zatíženy očekávanými odpověd'mi.

Z okódovaných výroků studentů $\mathrm{z}$ obou fakult byly vytvořeny čtyři kategorie: nevim; znalost; aplikace; znalost a aplikace. Uvádíme kvantitativní obsazenost kategorií před semestrem a po semestru, protože sledujeme, jak výuka (ne)pozmě- 
nila vnímání konceptu psychologická gramotnost u studentů. Tento kvantitativně vyjádřený pohyb mezi kategoriemi před a po semestru dále doplňujeme o kvalitativní analýzu vnímání kategorií samotných.

Tabulka 1 ukazuje, že studenti z PedF JU psychologickou gramotnost nejvíce vnímají před i po semestru v rovině znalostí (před semestrem $\mathrm{n}=60$, po semestru $\mathrm{n}=63$ ), dále $\mathrm{v}$ rovině znalostí $\mathrm{v}$ kombinaci $\mathrm{s}$ aplikací (před semestrem $n=26$, po semestru $\mathrm{n}=29$ ), méně $\mathrm{v}$ rovině aplikace (před semestrem $\mathrm{n}=15$, po semestru $\mathrm{n}=12$ ). Před semestrem i po semestru se vyskytovaly odpovědi „nevím“ (před semestrem $n=9$, po semestru $n=6$ ). Studenti z PedF UKB na začátku semestru vnímali psychologickou gramotnost zejména $\mathrm{v}$ rovině znalostí $(\mathrm{n}=45)$, dále $\mathrm{v}$ rovině znalostí a aplikace současně $(\mathrm{n}=27)$, následně $\mathrm{v}$ rovině nevím $(\mathrm{n}=18)$ a $\mathrm{v}$ rovině aplikace $(\mathrm{n}=10)$. Po absolvování výuky v jejich vnímání dominuje rovina znalostí v kombinaci s aplikací $(\mathrm{n}=59)$, dále znalostní rovina $(\mathrm{n}=20)$ a aplikace $(\mathrm{n}=20)$. Odpověd' nevím se vyskytla po semestru pouze jednou.

Pokud kognitivní dimenze $\mathrm{k}$ pojmu psychologická gramotnost opravdu implicitně odráží zkušenosti studentů $s$ výukou psychologie, jak předpokládáme, byly nastavené cíle výuky u obou dvou souborů přijaty. To se ukázalo již v hodnocení príínosu předmětů, a nyní i skrze analýzu slovního popisu pojmu psychologická gramotnost, protože na PedF JU po semestru stále převažovala znalostní rovina chápání tohoto pojmu, zatímco na PedF UKB rovina znalostní v kombinaci s aplikační. Zároveň statisticky významné rozdíly $\mathrm{k}$ pojmu psychologická gramotnost po semestru (u slovenského souboru v rovině vztahu i významu, u českého souboru v rovině významu) dovolují uvažovat o přijetí nastavených cílů výuky psychologie i v rovině afektivní.

Kvalitativní analýza dvou kategorií (znalosti, aplikace) upozorňuje ještě na potřebu jejich vnímání na škálách. U pojmu znalosti se pohybuje na škále: povédomi porozumění. Jinými slovy, v rovině znalostí se pohybujeme mezi póly: základy (přehled) - zvládání. U pojmu aplikace se pohybujeme na škále: obecnost - konkrétnost. Obecnost je $\mathrm{v}$ tomto př́padě zastoupena kódy praxe, užití v běžném a profesním životě. Konkrétnost se v odpovědích vyskytovala v těchto podobách: porozumění svému chování a chování druhých, rozpoznání, reagování na chování druhých, interpreta-

Tab. 1. Kognitivní dimenze pojmu psychologická gramotnost před semestrem a po semestru u studentů z PedF JU ( $\mathrm{N}=110)$ a PedF UKB $(\mathrm{N}=100)$

\begin{tabular}{|l|c|c|c|c|}
\hline \multirow{2}{*}{} & \multicolumn{2}{|c|}{ PedF JU $(\mathbf{N}=110)$} & \multicolumn{2}{c|}{ PedF UKB (N = 100) } \\
\cline { 2 - 5 } & před semestrem & po semestru & před semestrem & po semestru \\
\hline aplikace & 15 & 12 & 10 & 20 \\
\hline znalosti & 60 & 63 & 45 & 20 \\
\hline znalosti + aplikace & 26 & 29 & 27 & 59 \\
\hline nevím & 9 & 6 & 18 & 1 \\
\hline
\end{tabular}


ce jednotlivých př́ípadů v konkrétních situacích, předvídání chování druhých lidí, umění jednat $s$ lidmi v konkrétních situacích, empatie, umět poradit. $Z$ těchto odpovědí opět vyvstává otázka, do jaké míry jsou studenti schopni se na uvedených škálách pohybovat smèrem $k$ pólu porozumèni pojmuim (teoriím) a konkrétnosti $v$ roviné aplikovatelnosti, resp. jak výuku pozménit tímto smèrem. Touto otázkou se budeme zabývat v diskusní části.

\section{DISKUSE NAD VÝSLEDKY VÝZKUMU Z HLEDISKA CÍLŮ VÝUKY PSYCHOLOGIE}

Studenti z hlediska afektivní dimenze konotací $\mathrm{k}$ pojmům psychologie i psychologie pro učitelskou profesi, stejně jako $\mathrm{k}$ pojmu psychologická gramotnost tyto pojmy vnímají jako důvěryhodné, oblíbené a důležité, užitečné, známé, významné, potřebné, moderní, bezpečné. $Z$ toho usuzujeme, že i výuku psychologie hodnotí pozitivně. To dává dobrý předpoklad $\mathrm{k}$ případným změnám vedoucím ke zlepšení výuky psychologie.

Zároveň se ale na afektivní úrovni $\mathrm{k}$ uvedeným pojmům ukázaly rozdíly mezi českou a slovenskou skupinou. Na ty můžeme nahlížet např. $v$ kontextu tzv. socializace do profese (srov. Helus, 2015). Studenti druhého ročníku mohou měnit své postoje a potřeby ohledně výuky psychologie nejen $\mathrm{v}$ důsledku kurikulárních rozdílů a rozdílů ve vedení předmětu, ale také díky silnější identifikaci s profesí a uvědomování si významu psychologie pro učitelskou profesi.
Získaná data tedy dávají podnět $\mathrm{k}$ dalšímu semilongitudinálnímu zkoumání vlivu psychologické výuky na studenty učitelství.

Z hlediska cílů výuky psychologie připomeňme, že teoretickým východiskem cílů, ke kterým by měla směrovat výuka psychologie na vysoké škole pro učitelské obory, je obecně přijatý koncept funkční psychologické gramotnosti. Ten je podle Sokolové (2015) rozpracovaný do pěti oblastí: sebepoznání, vědecké myšlení, kritické myšlení, psychologické myšlení a další oblasti funkční psychologické gramotnosti (etická dimenze).

$Z$ výpovědí studentů vyplývá, že ve výuce na sledovaných pedagogických fakultách v ČR a SR primárně bylo na úrovni koncepční formy obsahu vzdělávání rozvíjené vědecké myšlení (v rovině znalostí a jejich porozumění), dále sebepoznání a poznání druhých. Kritické myšlení, psychologické myšlení a etiku studenti explicitně neuváděli. Respektive z nich uváděli pouze aplikační část $\mathrm{v}$ obecné rovině. Právě tyto dimenze funkční psychologické gramotnosti kritické myšlení a psychologické myšlení na úrovni vyhodnocování informací, komunikace s různými lidmi a respektování jejich rozmanitosti - se ukazují jako stěžejní pro správné uchopení aplikační roviny. Připomeňme, že aplikační rovinu výuky studenti nejvíce oceňovali a zároveň nejvíce vyžadovali.

Pokud ale aplikace není rozvíjena spolu s psychologickým a kritickým myšlením, výuka může vést $\mathrm{k}$ tomu, co jeden student popsal těmito slovy: „Nedokážu si př́edstavit, že něco z toho aplikuju 
na žáka a ono to pomůže a nebude mít ze mě akorát srandu" (PedF JU). Výpověd' studenta zároveň ukazuje na problém, kdy studenti velmi obtížně nebo dokonce nesprávně provádějí transfer získaných znalostí do běžného a profesního života. Tím doporučení a návody bez hlubšího porozumění kontextu mohou být degradovány na úroveň „kuchařek“.

Problematiku aplikační úrovně znalostí dobře ukazuje požadavek studentů na osobnostni testy u českého souboru. Studenti kladně hodnotí tento typ „testování" a přejí si ho mít ve výuce více. Slovo „testováni'“ jsme daly záměrně do uvozovek, protože $\mathrm{v}$ hodinách nebyly použité standardizované testy, ale nestandardizované dotazníky (napřr. na pozornost, motivaci, inteligenci). Záměrem jejich užití bylo: (a) v osobnostní rovině zamyšlení se nad výsledky ve vztahu $\mathrm{k}$ tomu, co o sobě studenti již vědí, (b) ilustrace probíraných témat, (c) současně snaha vést studenty ke kritickému náhledu na tento typ „testování“. Výpovědi studentů však ukazují spíše ke stereotypnímu vnímání a užití tohoto způsobu „testování“ než $\mathrm{k}$ jejich kritickému reflektování.

Problém aplikační roviny poznatků tedy vidíme ve dvou zjištěných obecných stereotypech vnimáni psychologie: (1) véda, která dává rady, návody, tj. „kuchařky“ (2) a umožňuje "testovat" a poskytuje "testy“. Tyto stereotypy vnímání psychologie označujeme za kritické oblasti cílù výuky psychologie, které by měly být dále zkoumány např́ic formami obsahu vzdělávání: od projektové formy přes realizační a rezultátovou až po formu efektovou.

\section{ZÁVĚR}

Výuka psychologie pro učitelské obory se odehrává na průniku obecné koncepce funkční psychologické gramotnosti, současného nastavení výuky psychologie pro učitele v ČR a SR, osobních cílů a potřeb studentů, profesních cílů studentů učitelství (obr. 1). Podle Průchovy koncepce forem kurikula mluvíme o koncepční, projektové, realizační, rezultátové a efektové formě.

V článku jsme se na tento průnik dívaly skrze reflexi výuky psychologie studenty (rezultátovou formu) na dvou pedagogických fakultách (v ČR a SR). Studenti na obou dvou fakultách přijali nastavený cíl výuky psychologie daného předmětu (projektovou formu), který byl na fakultách rozdílný a promítl se do vnímání pojmu funkční psychologická gramotnost po semestru. $\mathrm{V}$ realizační formě sice kladně hodnotili, zároveň ale $\mathrm{i}$ vyžadovali větší zařazení aplikační roviny. To je ve shodě s koncepční formou - funkční psychologickou gramotností. Funkční psychologická gramotnost se netýká jen porozumění základním psychologickým principům, ale také schopnosti jejich uplatnění v praxi s ohledem na osobní, profesní a společenské potřeby (Cranney \& Dunn, 2011; Cranney, Botwood \& Morris, 2012). Je zde ovšem otázka jejího konkrétního uchopení. Bez rozvoje kritického a psychologického myšleni může totiž vést ke stereotypům vnímání psychologie, kterými jsou: (1) psychologie jako véda, která dává rady, návody, tj. „kuchařky" a (2) umožňuje "testovat" a poskytuje "testy". 
Uvedené stereotypy vnímání psychologie tudíž stojí na opačném pólu od funkční psychologické gramotnosti. Identifikaci těchto kritických oblastí cílů výuky psychologie spojených $s$ aplikační rovinou by měla být věnovaná pozornost napřric formami obsahu vzdělávání: od projektové formy po efektovou. Ukazuje se, že stěžejní pro výuku samotnou (realizační formu) je rozvoj kritického a psychologického myšlení. Metodickým doporučením pro jejich rozvoj mohou být např́iklad problémové, diskusní či případové metody, práce $s$ autentickým textem, dále metody jako je dvojité kolečko, hodnoticí mřížka, čtyři rohy, které studenty nabádají k nahlížení na psychologické problémy a koncepty $\mathrm{z}$ různých uhlů, $\mathrm{k}$ argumentaci a kritickému hodnocení psychologických teorií, výzkumů apod. (inspiraci k metodám je možné najít např́iklad v knize Sokolové, 2015). Tento prrístup $\mathrm{k}$ výuce psychologie má potenciál připravovat učitele jako kritic-

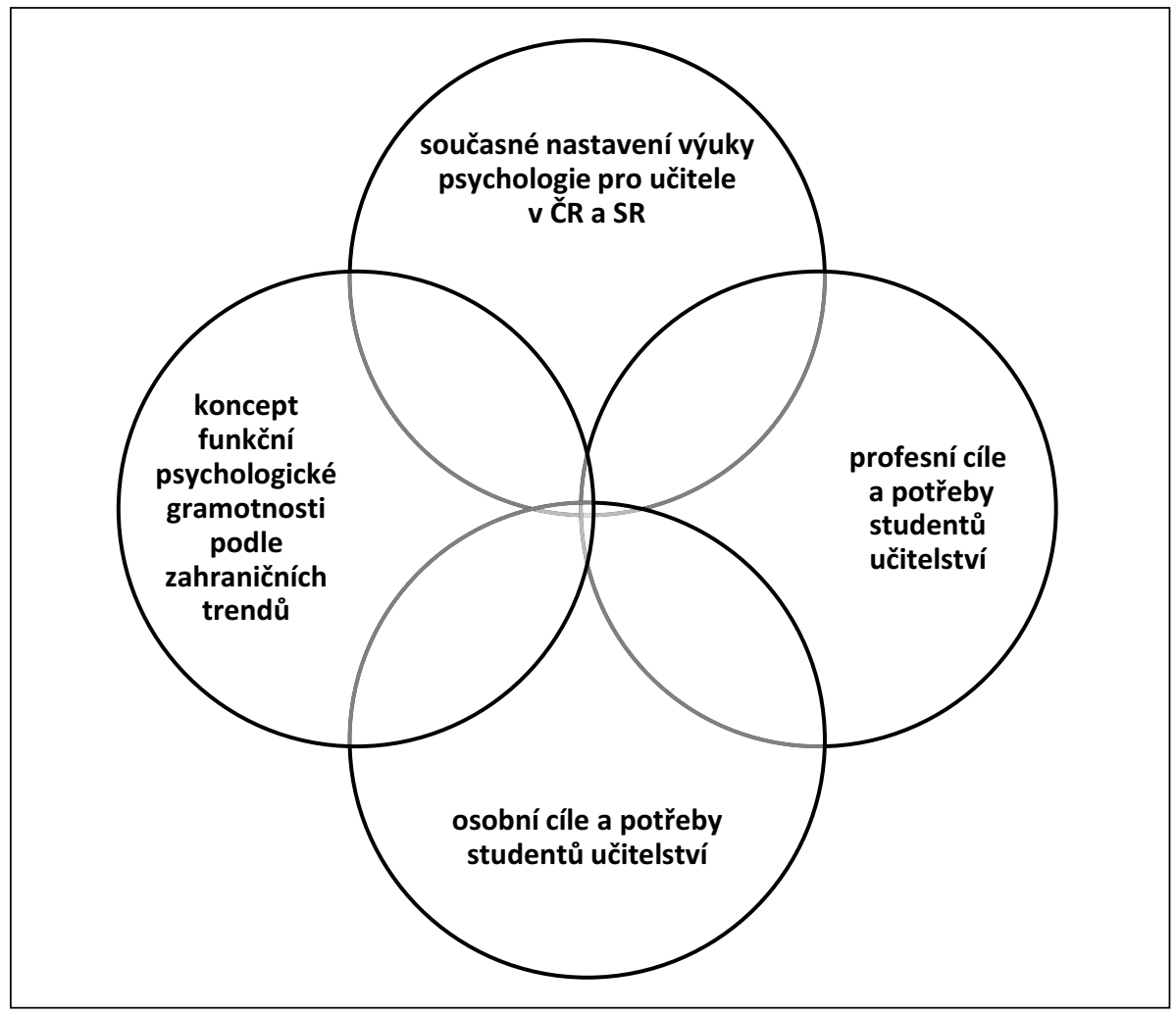

Obr. 1. Propojení stěžejních částí obsahu vzdělávání v psychologii 
ké uživatele psychologického poznání, kteří budou schopni nejen pojmenovat psychologické znalosti a použít je ve své pedagogické praxi, ale také usuzovat a vybírat si odborně relevantní a kvalitní psychologické produkty a služby, které se školám nabízejí.

\section{Literatura}

Augustin, W. (2012). What do our students think of studying psychology? EFPTA Newsletter, 1, 15-19. Dostupné z www.efpta.org

Boneau, C. A. (1990). Psychological literacy: A first approximation. American Psychologist, 45(7), 891-900. Cranney, J., Botwood, L., \& Morris, S. (2012). National standards for psychological literacy and global citizenship: Outcomes of undergraduate psychology education. Sydney: The University of New South Wales. Dostupné z www.groups.psychology.org.az

Cranney, J., \& Dunn, D. (Eds.). (2011). The psychologically literate citizen: Foundations and global perspectives. New York: Oxford University Press.

Doulík, P., \& Škoda, J. (2003). Tvorba a ověření nástrojů kvantitativní diagnostiky prekonceptů a možnosti jejího vyhodnocení. Pedagogika, 53(2), 177-189.

Dunn, D. S., Baker, S. C., Mehrotra, C. M., Landrum, R. E., \& McCarthy, M. A. (Eds.). (2013). Assessing teaching and learning in psychology. Current and future perspectives. Belmont, CA: Wadsworth.

Halpern, D. F. (Ed.). (2010). Undergraduate education in psychology: A blueprint for the future of the discipline. Washington, D. C.: American Psychological Association.

Helus, Z. (2015). Sociálni psychologie pro pedagogy. Praha: Grada.

Chrz, V., Nohavová, A., \& Slavík, J. (2015). Psychologická gramotnost ze dvou poznávacích perspektiv: aktuální výzva pro výuku psychologie a její didaktiku. Studia paedagogica, 20(3), 21-46.

Mair, C., Taylor, J., \& Hulme, J. (2013). An introductory guide to psychological literacy and psychologically literate citizenship. York: The Higher Education Academy.

McGovern, T. V., Corey, L. A., Cranney, J., Dixon, Jr., W. E., Holmes, J. D., Kuebli, J. E., ... Walker, S. (2010). Psychologically literate citizens. In D. Halpern (Ed.), Undergraduate education in psychology: Blueprint for the discipline's future (s. 9-27). Washington: APA.

Morris, S., Cranney, J., Jeong, J. M., \& Mellish, L. (2013). Developing psychological literacy: Student perceptions of graduate attributes. Australian Journal of Psychology, 65, 54-62.

Pravdová, B., \& Švec, V. (2014). Pedagogické praxe jako prostor pro integraci poznatků z psychologických a pedagogických disciplín. In Jan Mareš (Ed.), Učime psychologii (s. 5-10). Brno: Masarykova univerzita. (Online). Dostupné z https://is.muni.cz

Průcha, J. (2005). Moderni pedagogika. Praha: Portál.

Průcha, J. (Ed.). (2009). Pedagogická encyklopedie. Praha: Portál.

Slavík, J., Janík, T., Najvar, P., \& Knecht, P. (2017). Transdisciplinárni didaktika: o učitelském sdileni znalostí a zvyšováni kvality výuky napríć obory. Brno: Masarykova univerzita.

Sokolová, L. (2015). Metódy vyučovania psychológie a predmetov osobnostného a sociálneho rozvoja. Bratislava: Univerzita Komenského. 
Sokolová., L. (2018). Psychologická gramotnost ako ciel' psychologického vzdelávania. In J. Duchovičová, D. Gunišová, N. Kozárová \& R. Š. Koleňáková (Eds.), Inovatívne trendy v odborových didaktikách $v$ kontexte požiadaviek praxe (s. 206-212). Nitra: Univerzita Konštantína Filozofa v Nitre.

Stuchlíková, I., \& Janík, T., et al. (2015). Oborové didaktiky: vývoj-stav-perspektivy. Brno: Masarykova univerzita.

Švaříček, R., \& Šedová, K. (Eds.). (2007). Kvalitativni výzkum v pedagogických védách. Praha: Portál. Taylor, J., \& Hulme, J. A. (2015). Psychological literacy: A compendium of practice. Dostupné z: http://eprints.bournemouth.ac.uk

Žlábková, I., \& Krninský, L. (2013). Pohled studentů učitelství na reflektivní a transmisivní př́stup k učení. ACORát, 2(1), 19-27.

Mgr. Alena Nohavová, Ph.D.

Pedagogická fakulta JU v Českj́ch Budějovicích, Katedra pedagogiky a psychologie

e-mail:nohava01@pf.jcu.cz

Mgr. Lenka Sokolová, Ph.D.

Pedagogická fakulta UKv Bratislave, Katedra psychológie a patopsychológie

e-mail: sokolova@fedu.uniba.sk

NOHAVAVÁ, A., SOKOLOVÁ, L. Student Teachers' Perceptions of the Educational Content and Goal of Psychology Courses

The study aims to analyze the objectives of the teaching of psychology in teacher education related to the educational content. We analyze this aspect of a curriculum through the reflections of students who attended psychology courses at two faculties of education: one in the Czech Republic and one in Slovakia. Based on general objectives of psychology teaching (functional psychological literacy) the study presents a critical view of the applied level of psychology teaching, which is positively evaluated by students. It may, however, lead to general stereotypes about psychology: (1) a main role of psychology is to advice, provide guides, so called "cooking books", (2) psychology enables us to use "tests" and to "test" people. These stereotypes stand on the opposite pole to functional psychological literacy. More attention should be paid to the identification of these areas of learning objectives related to the applied teaching of psychology across the curriculum. We suggest developing critical and psychological thinking.

Keywords: functional psychological literacy, students' expectations, students' attitudes, the teaching of psychology, learning stereotypes, curriculum. 